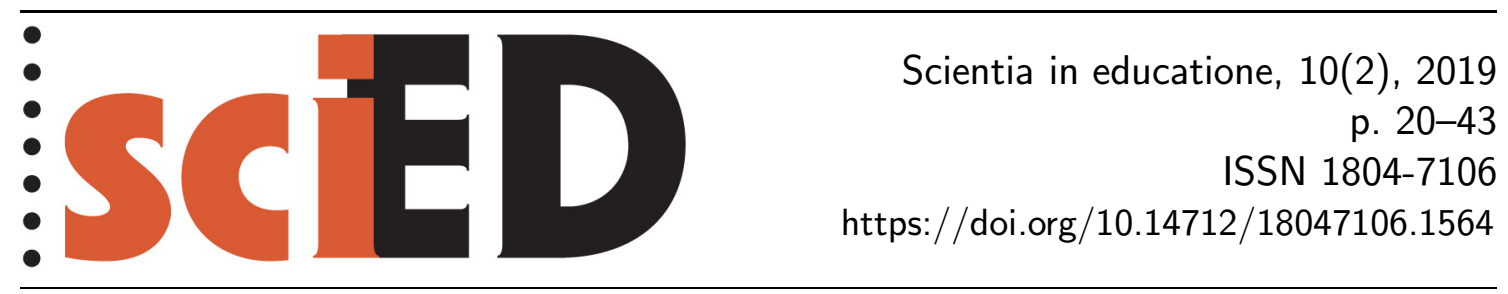

\title{
Pedagogická praxe studentů učitelství biologie z pohledu hospitačních rozhovorů
}

\author{
Linda Němečková, Lenka Pavlasová
}

\begin{abstract}
Abstrakt
Pedagogická praxe je jednou z důležitých součástí př́ípravy budoucího učitele a klíčové místo v jejím průběhu zaujímají hospitační rozhovory mezi studentem a garantem praxe. Článek popisuje analýzu hospitačních rozhovorů u studentů učitelství biologie, které byly vedeny s cílem zjistit, kterými aspekty výuky se studenti zabývají, které opomíjí a které jim př́padně působí potíže. Zaměřili jsme se na oborově specifické jevy v hodinách přírodopisu a biologie v pěti oblastech: cíle výuky, rozsah a obsah učiva, volba pomůcek a způsob práce $\mathrm{s}$ učivem, chyby studentů v roli učitele a chyby žáků a oblíbenost témat a motivace. Respondenty výzkumného šetření byli studenti učitelství biologie $(n=35)$, kteří v rámci svého navazujícího magisterského studia absolvovali praxe na základních či středních školách. Nejčastěji studenti stanovovali pouze kognitivní výukové cíle a ty byly formulovány především pomocí obsahu učiva. Klíčové kompetence a aktivní slovesa byla při stanovení cílů použita $\mathrm{v}$ malé míře. Rozsah učiva byl nejčastěji určován fakultním učitelem př́íp. zvyklostmi dané školy, konkrétní zastoupené organismy ve výuce byly nejčastěji vybrány pomocí učebnice. Velká část respondentů byla schopna uvést konkrétní chyby, kterých se při výuce dopustili, ovšem k chybám žáků se respondenti až na jednu výjimku nevyjadřovali. Jako nejběžnější způsob motivace žáků byla uváděna názornost použitím různých výukových pomůcek. Domníváme se, že zjištěné výsledky mohou přispět ke zkvalitňování př́pravy studentů učitelství biologie zejména $\mathrm{v}$ oblasti vedení hospitačních rozhovorů při souvislých pedagogických praxích.
\end{abstract}

Klíčová slova: hospitační rozhovor, pedagogická praxe na SS̆, pedagogická praxe na ZS̆, vyučovací hodina prŕrodopisu/biologie.

\section{Reflective teaching practice of future biology teachers from the point of view of observation interviews}

\begin{abstract}
Reflective practice is an important part of a future teacher's training and the interviews between the student teacher and the supervisor play a key role during this practice. The article describes an analysis of interviews with pre-service teachers of biology conducted within the supervision process. These interviews sought to establish which aspects of
\end{abstract}


teaching the pre-service teachers were dealing with, which ones they tended to omit, and which ones they found challenging. We focused on subject-specific phenomena in biology lessons in five areas: teaching objectives, the scope and content of subject matter, selection and the procedure of working with teaching materials/aids, mistakes made by the preservice teachers and pupils, the popularity of topics and motivation. The respondents of the research were pre-service teachers of biology $(n=35)$, who were in their follow-up master's degree program, completing their pedagogical practice at either lower or upper secondary schools. Most often the pre-service teachers set only cognitive objectives which were formulated primarily using the content of the curriculum. Key competences and active verbs were only used in a limited extent when their objectives were being set. The scope of the curriculum was most often determined by the supervising teacher or the customary range taught in that particular school, while the presented organisms were most often determined by the textbook. A large number of respondents were able to mention the specific mistakes they had made in the classroom, yet they did not comment on the pupils' mistakes, with one notable exception. The most common way of motivating pupils was using illustrations with various teaching aids. We believe that the results can contribute to improving the preparation of pre-service biology teachers, especially in the field of interviews with supervisor conducted within the continuous teaching practice.

Key words: interview with supervisor, reflective practice at lower secondary schools, reflective practice at upper secondary schools, biology lesson.

Pedagogická praxe je jednou z důležitých součástí přípravy budoucího učitele. Student učitelství zde má poprvé možnost vyzkoušet si výuku v reálné třídě a konzultovat svoje výstupy s fakultním učitelem i garantem praxí. Hospitační rozhovory mezi studentem a garantem praxe zde mají klíčové místo, ale pokud je nám známo, nebylo jim v odborné literatuře zatím věnováno př́liš pozornosti (Barnett \& Friedrichsen, 2015). Z tohoto důvodu jsme provedli analýzu hospitačních rozhovorů u studentů učitelství biologie, abychom zjistili, kterými aspekty výuky se studenti zabývají, které opomíjí a které jim případně působí potíže.

Na Pedagogické fakultě Univerzity Karlovy probíhají souvislé výukové praxe u oboru Učitelství všeobecně vzdělávajících předmětů pro základní školy a střední školy - biologie následujícím způsobem. Každý student nejprve absolvuje praxe na základních školách, příp. nižších ročnících osmiletých gymnázií, a to v rámci letního semestru prvního ročníku navazujícího magisterského studia, a poté absolvuje praxi na středních školách, příp. vyšších ročnících osmiletých gymnázií, v zimním semestru druhého ročníku navazujícího magisterského studia. Studenti jsou povinni účastnit se 8 náslechových vyučovacích hodin a 12 vlastních vyučovacích hodin. Ještě před souvislými praxemi je zařazena náslechová praxe (zimní semestr prvního ročníku).

Kontrola souvislé praxe může probíhat dvojím způsobem podle výběru a možností studenta. Studenti mohou volit osobní návštěvu hospitujícího, nebo formu tzv. videohospitace. Pokud studenti zvolí právě formu videohospitace, tak po odučení natočené vyučovací hodiny píší volnou reflexi, kde se samostatně vyjadřují k situacím a jevům, které sami považují za důležité. Délka reflexe není omezena. Reflexe je odevzdána nejpozději do 24 hodin od uskutečnění výuky. Dále jsou studenti povinni zhlédnout videozáznam z téže vyučovací hodiny a na základě videonahrávky píší druhou reflexi téže vyučovací hodiny. Opět není omezena délka ani obsah reflexe. Každý student se posléze setká s garantem praxí, se kterým dojde k rozboru vyučovací hodiny. Hospitační rozhovor má obvykle tři části. Nejprve je student vyzván, 
aby samostatně shrnul průběh natočené vyučovací hodiny, následují obecné otázky týkající se oboru a oborové didaktiky stejné pro všechny studenty a dále otázky zacílené na několik vybraných klíčových oborových nebo oborově didaktických jevů, které považuje garant praxí v hodině za důležité.

Kvalita vyučovací hodiny a výuky vůbec je dána několika komponenty, a to jak oborově obecnými, jako je např. klima ve tř́idě, tak i oborově specifickými (Janík, Lokajíčková \& Janko, 2012). Z důvodu zkvalitňování př́ipravy studentů učitelství na svoji budoucí výuku př́rodopisu/biologie jsme se rozhodli zaměřit na oborově specifické jevy v hodinách přírodopisu/biologie a zjistit, jakým zpơsobem s obsahem a dalšími aspekty výuky studenti Pedagogické fakulty Univerzity Karlovy pracují. Pomocí hospitačních rozhovorů jsme se snažili působit na rozvoj profesního vidění u studentů tak, aby se studenti zaměřovali především na zmíněné oborově specifické jevy.

\section{TEORETICKÁ VÝCHODISKA}

\subsection{PEDAGOGICKÉ PRAXE}

Ve výzkumu Kuruce (2016) tvořila skupina studentů s pozitivními zkušenostmi s praxí, př́íp. se špatnými zkušenostmi, které však nikterak neovlivňovaly jejich tendence směřovat k učitelskému povolání, nejméně početnou skupinu. Ostatní skupiny vyjádřily své negativní zkušenosti, které během povinné praxe nabyly. Pravdou je, že celých $40 \%$ začínajících učitelů v profesi, kterou si vybrali, nevydrží déle než čtyři roky (Bernshausen \& Cunningham, 2001). Důvodem může být tzv. šok z reality, která se neslučuje s představami studentů učitelství o žácích a chodu školy (Veenman, 1987). Dále např. dle výzkumu Lojdové (2014) se studenti během praxí často setkávali s odbornými nedostatky a často zmiňovali i soudy o vhodnosti či naopak špatné volbě budoucího povolání. Bez ohledu na to, zda je možné výsledky zmíněných výzkumných šetření generalizovat či nikoliv, je zajisté podstatné o zmíněných negativních zkušenostech přemýšlet jako o potencionální realitě, která se může odehrávat v myslích studentů učitelství.

Některé situace, které mají vliv na pozitivní či negativní pohled studentů učitelství na pedagogické praxe, mají ve svých rukách i fakultní učitelé. Důvodem je, že se studenti na praxích ocitají v tzv. dvojí roli, kdy podléhají kontrole cvičného učitele a zároveň kontrolují práci žáků. Fakultní učitel je někdy může uvést do nepř́ijemné pozice, a to v případě, že opraví postup studenta přímo před žáky. Student by měl být z role kontrolujícího do role kontrolovaného postaven v určeném prostoru bez přítomnosti žáků (Lojdová, 2014).

Někdy k zamezení získání špatných pocitů mohou přispět i zdánlivé maličkosti, jako je např. představení studenta žákům a jejich podpora ze zadních lavic (Lojdová, 2014). Mezi další momenty, kterými fakultní učitelé přispívají k pozitivním pocitům studentů při praxi, patří předávání repertoáru nejrůznějších rituálů a symbolů. Jedná se o použivání červeného pera při opravě žákovských prací či vyžádání si žákovské kní̌ky při vyrušování žákem, přičemž žákovská knížka je nejprve jako výstraha umístěna na katedru tak, aby žákům připomínala možný důsledek jejich nežádoucího chování (Lojdová, 2014).

Jedním z hlavních doporučení, která se nejenom k začínajícím učitelům pojí, je proces sebereflexe. Reflektivní dovednosti by však měly být osvojeny již v průběhu studia tak, aby i nadále v profesi docházelo k jejich rozvoji (Dytrtová, 2009; Lojdová, 
2014; Janík, Píšová \& Spilková, 2014). Je totiž zapotřebí brát v potaz i rizika, která s osvojováním dovedností sebereflexe souvisí. Někteří jedinci totiž prožívají nepříjemné stavy při zjištění nesouladu aktuálního já s ideálním já, příp. požadovaným já. Mnozí jedinci se tak sebereflexi mohou záměrně vyhýbat (Urbanovská, 2002). Z výzkumu Pravdové (2013) je však patrné, že ačkoliv je pojem profesní já tak důležitý z hlediska profesního rozvoje, respondentka zmíněného výzkumu se s ním poprvé setkala až v posledním ročníku svého studia, dokonce až během výzkumného šetření.

Sebereflexe a sebehodnocení patři mezi faktory, které utvářejí a rozvíjejí pedagogické dovednosti studenta (Švec, 2017). Autoevaluační procesy u studentů kromě fakultních učitelů na škole mohou posilovat také vysokoškolští učitelé (garanti praxí), kteří mohou vystupovat v roli tzv. mentora. Je dokázáno, že studenti učitelství, kteří během mentorských rozhovorů zažívají pozitivní interakce s mentorem, vykazují také vyšší hodnoty ve výsledcích učení (Tillema \& Van der Westhuizen, 2013). Ze studie (Barnett \& Friedrichsen, 2015) je zřejmé, jak mentor pomohl rozvinout specificky oborové znalosti studenta učitelství, když došlo k odhalení jeho miskoncepcí při mentorském rozhovoru.

V námi provedeném výzkumu jsme se soustředili na pět oblastí vyučovací hodiny, na které byli studenti cíleně dotazováni během hospitačních rozhovorů a které blíže rozebereme v následujícím textu. Jedná se o cíle výuky, obsah a rozsah učiva, pomůcky a způsob prezentace učiva, chyby studentů učitelství v roli učitele, chyby žáků, oblíbenost témat a motivace.

\subsection{VÝUKOVÉ CÍLE}

V anglické literatuře, která se věnuje pedagogické terminologii, se setkáváme se dvěma pojmy, které se s cíli pojí. Je nutné rozlišovat mezi cíli obecnými, neboli goals, a mezi cíli dílčími, které jsou měřitelné, jedná se o tzv. objectives (Pasch, 1998). V české literatuře byly tyto pojmy bliže popisovány v díle Byčkovského a Kotáska (2004), kde jsou tzv. educational objectives použivány pro označení zamýšlených, resp. očekávaných, výsledků vzdělávacího procesu u žáků.

"Výukové cíle jsou první podstatou pro smysluplné učení a efektivní vyučování." (Moss \& Brookharta, 2012: s. 11). Jedná se o popis cílového stavu procesu učení žáků (Kyriacou, 2012). Stanovování výukových cílů je záměrné z toho důvodu, že napomáhá nejen $\mathrm{k}$ výběru, ale i k následnému efektivnímu užívání výukových strategií, které jsou vhodné pro učení žáků (Stará \& Starý, 2018).

Dalším významem stanovování cílů je vytvoření struktury v rámci procesu učení žáků. Pokud je naším záměrem, aby žáci ke splnění cílů na konci vyučovací hodiny došli, je zapotřebí, aby žáci cílům rozuměli a dokonce se s nimi identifikovali (Stará \& Starý, 2018).

Velmi důležité je i vymezení cílů a jejich zaměření. Cíle by měly být stanoveny tak, aby je žáci měli možnost přizpůsobit svým potřebám a zájmům (Skalková, 2012; Stará \& Starý, 2018). Cúle jsou tvořeny třemi složkami - složkou vzdělávací (kognitivní), postojovou (afektivní) a složkou výcvikovou (psychomotorickou). Je zapotřebí, aby učitel toto měl na paměti a do výuky zařazoval takové aktivity, které se podílejí na rozvoji všech těchto složek výukových cílů (Kalhous \& Obst, 2000; Švec, Filová \& Šimoník, 2004). Jako pomůcka pro stanovování cíle se používají různé taxomomie (Kalhous \& Obst, 2000). Jejich společným jmenovatelem je doporučení využívání tzv. aktivních sloves. Z modernějších je to např. taxonomie uvedená v publikaci Marzano a Kendall (2007), která je pojata jako dvoudimenzi- 
onální model. Jedna dimenze zahrnuje mentální procesy a druhá dimenze zahrnuje znalosti (Marzano \& Kendall, 2007).

Vhodné je plánování cílů, kterých mají žáci na konci vyučovací hodiny dosáhnout tzv. metodou „plánování pozpátku“. Učitel nejprve stanoví cíle. Poté se zaměří na formulaci konkrétního zadání pro žáky, ve kterém žáci projeví svůj „cílový stav“. Následuje fáze, při které učitel naplánuje takové úkoly apod., kterými žáci musí projít, aby byli schopni toto zadání vypracovat co nejkvalitněji (Koštálová \& Hausenblas, 2004).

V Rámcových vzdělávacích programech jsou cíle vzdělávání vyjádřeny pomocí kompetencí (RVP ZV, 2005: s. 10; RVP G, 2007: s. 8), které představují „soubor vědomostí, dovedností, schopností, postojů a hodnot, které jsou důležité pro osobní rozvoj jedince, jeho aktivní zapojení do společnosti a budoucí uplatnění v životě“. V RVP ZV jsou uvedeny kompetence $\mathrm{k}$ učení, $\mathrm{k}$ řešení problémů, komunikativní, sociální a personální, občanské a pracovní. V RVP G jsou uvedeny kompetence k učení, k řešení problémů, komunikativní, sociální a personální, kompetence občanská a kompetence $\mathrm{k}$ podnikavosti. I zde by měl učitel cílit na utváření a rozvoj více kompetencí, a ne jen kompetence k učení.

Pokud hovoříme o výukových cílech, měli bychom vždy mít na paměti i poskytování zpětné vazby. $\mathrm{V}$ př́ipadě, že žáci nejsou obeznámeni s tím, kam ve výuce směřují, nemohou pochopit, zda se jim daří či naopak (Stará \& Starý, 2018). Kvalitní zpětná vazba tedy může být žákům poskytnuta až poté, co došlo ke správnému zformulování výukových cílů. Následná zpětná vazba je pak po explicitním vyjádření výukových cílů také nezbytná (Kalhoust \& Obst, 2000; Stará \& Starý, 2018).

\subsection{OBSAH A ROZSAH UČIVA}

Obsahem učiva se rozumí souhrn vědomostí, dovedností, schopností, postojů a zájmů, které jsou osvojené během vzdělávacího procesu. V českém prostředí je určen Rámcovými vzdělávacími programy (RVP ZV, 2005; RVP G, 2007), podle kterých si škola zpracovává své vlastní školní vzdělávací programy. Existuje několik determinantů, které určují, s čím by se žáci ve vyučování měli seznámit. Mělo by se jednat o informace a dovednosti, které žák zužitkuje především v rámci svého působení ve společnosti, tyto informace a dovednosti by měly odrážet vývoj vědy a praxe a měly by rozvíjet žáka vzhledem k jeho možnostem, potřebám a zájmům (Vohra, 2000; Vališová \& Kasíková, 2007; Stuckey, 2013). Rozsah a obsah vzdělávání má tedy být volen s důrazem kladeným na redukci obsahu učiva $\mathrm{v}$ př́rodovědných předmětech, vzájemné vztahy mezi vědou, technikou a společností (Škoda \& Doulík, 2009). Dle Jelemenské (2007) je zapotřebí vytvářet takový obsah biologického učiva, který odráží především skutečnou živou přírodu a potřeby praxe. Dalším požadavkem je i potřeba naučit žáky učit se. Pojmy, zákony a metody př́rodovědného poznání mají široký „průřezový" charakter, je tedy žádoucí mezi sebou různé př́rodovědné vzdělávací obsahy navzájem propojovat (Maršák \& Janoušková, 2006).

\subsection{POMŮCKY A ZPŮSOB PREZENTACE UČIVA}

Př́rodniny nebo jejich preparáty by měly tvořit co největší část pomůcek učitelů biologie. Důležité jsou také odlitky a modely př́rodnin (Pavlasová, 2014). Učitel by neměl zapomínat, že většina informací ve výuce by měla být předávána vizuálně, nebot $87 \%$ informací vstupuje do mozku žáků právě zrakem (Petty, 1996). Není tedy divu, že učitelé ve svých hodinách použivají velmi často také obrázky 
a videa organismů, které jsou často prezentovány pomocí prezentace promítané diaprojektorem. Mezi často používané literární pomůcky jsou také řazeny nejrůznější nakladatelství učebnic př́rodopisu a biologie, pracovní sešity či pracovní listy, dále pak atlasy a určovací klíče (Pavlasová, 2014).

Díky charakteristickým výukovým metodám a organizačním formám využívaných speciálně v hodinách př́rodopisu/biologie, jako jsou laboratorní cvičení, pokusy a exkurze, by učitelé, resp. žáci, často měli používat nástroje (např. lupy, pinzety entomologické sítě) a přístroje (mikroskopy, binolupy) umožňující přímé studium př́rody (Pavlasová, 2014; Pavlasová et al., 2015).

Učitelé by také měli vycházet $\mathrm{z}$ názorů žáků a připravovat takovou výuku, která je pro žáky nejpříjemnější a nejlépe se při ní podle jejich mínění učí. Jedná se o zařazování nejrůznějších druhů skupinového učení, využívání ICT, hraní didaktických her, praktickou výuku v laboratořích a zařazování exkurzí (Sitná, 2009).

Dle požadavků na přírodovědné vzdělávání nemá být žák pouze pasivním příjemcem poznatků, které učitel předává, ale má se sám aktivně podílet i na jejich hledání, hodnocení a využivání k různým účelům (Maršák \& Janoušková, 2006). Čeští žáci mají sice osvojeno velké množství př́rodovědných poznatků, ale jejich nedostatky se objevují v oblasti samostatného uvažování, zkoumání, vytváření hypotéz, hledání a navrhování cest apod. při řešení přírodovědných problémů (Papáček, 2010). Jak vyplývá z mezinárodního šetření PISA, průměrné výsledky, kterých žáci dosahovali v roce 2006, se navíc v roce 2015 ještě zhoršily. Dotazníkové odpovědi žáků byly následně porovnávány s jejich výsledky v testech. Bylo zjištěno, že ti žáci, kterým učitelé vysvětlují vědecké myšlenky v hodinách často, dosahují v testu více bodů. Stejná tendence lze pozorovat, pokud mají žáci možnost diskutovat jejich dotazy, či v případech, že jejich učitelé názorně demonstrují nějaké myšlenky. Velmi důležité, především s ohledem na vysoký motivační potenciál, je zařazování experimentů do výuky (Blažek \& Př́íhodová, 2016).

Doporučovanými postupy či metodami, které lze často spatřit i v požadavcích žáků (viz výše), jsou skupinové práce, individualizovaná výuka, kooperativní a projektová výuka apod. Maršák a Janoušková (2006), dále pak např. Rocard et al. (2007), uvádějí jako jednu z vhodných metod pro zvyšování zájmu žáků u předmětů typu „science“ badatelsky orientovanou výuku. Obecně je v prŕrodovědných předmětech doporučováno zvýšení podílu induktivního přístupu k výuce oproti v současnosti často převažujícímu přístupu deduktivnímu. Induktivní (badatelsky nebo problémově orientovaný) přistup je obecně doporučován jako základní opatření ke zvýšení zájmu i dosažených výsledků žáků v přírodovědných předmětech (Rocard, 2007).

\subsection{Chyby STUDENTŮ UČITELSTVí V ROLI UČITELE A CHYBY ŽÁKŮ}

Těžkostí, se kterými se začínající učitelé musí během výuky vypořádat, je značné množství. Může se jednat nejenom o potíže s obsahem předmětu, ale také o zvládnutí procesu výuky z hlediska managementu, časové organizace, formulace pokyno̊, pohybu po tř́dě, intonace hlasu apod.

Existují rozdíly v tom, jakým způsobem se studenti učitelství hodnotí sami a mezi tím, jak je hodnotí oboroví didaktikové. Za činnosti, které studenti učitelství vnímají jako nejhưře zvladatelné, se řadí časové rozvržení učiva, udržení kázně, grafický projev a psaní na tabuli, řešení kázeňských přestupků, udržování pozornosti žáků a správná formulace otázek (Wernerová, 2009). 
Mezi jednou z nejlépe hodnocených činností, jak mezi studenty učitelství, tak mezi oborovými didaktiky, je uvedena i organizace aktivit v hodině (Wernerová, 2009). Naopak Barbetta, Norona a Bicard (2005) uvádějí, co se týká řízení třídy, jednou z častých chyb studentů učitelství je nedostatečné plánování přechodů ve výuce. Nevhodně provedené či dokonce nepřipravené přechody mezi jednotlivými činnostmi žáků se mohou projevit ztrátou velkého množství času, př́ip. mohou být přičinou negativních interakcí mezi žáky a učitelem. Důležité je, aby přechody byly konzistentní (stejná pravidla pro každý typ přechodu), aby učitel nepřecházel k další činnosti, aniž by všichni žáci splnili předchozí pokyny (Barbetta, Norona \& Bicard, 2005).

Z výsledků studie (Yip, 1998) je patrné, že v oblasti obsahu předmětu, tedy znalostí oboru, mají začínající učitelé biologie několik miskonceptů, které se týkají metabolismu buněk, mechanismu fotosyntézy, procesu výživy, výměny látek v kapilárách, homeostázy, regulace teploty těla, vodního režimu v rostlinných tělech, reprodukce a adaptace na prostředí. Konkrétně studenti učitelství často př́liš zjednodušují výroky týkající se procesu fotosyntézy a jejich mechanismů. Jedním z těchto výroki̊ je: „Proces fotosyntézy se skládá ze světelné a temnostní fáze." Na základě těchto výroků u žáků mohou vznikat takové miskoncepty, že tzv. temnostní fáze probíhá pouze za tmy nebo v noci. Někteří žáci dokonce ztotožňovali temnostní fázi s procesem respirace (Yip, 1998). Další z miskonceptů uvedených v textu Yipa (1998) je i výrok, že: „Pylová zrna u rostlin jsou totéž, co spermie u zvírat.“ Tato mylná informace může zapř́ičinit, že se žáci mohou domnívat, že z důvodu malé velikosti pylových zrn se jedná o počáteční stádium samčích rostlinných gamet.

Oborové miskoncepty učitele se dají velice dobře zjistit právě z videozáznamu hodin (viz Jáč, 2017a). Oborová správnost učiva je přitom základním předpokladem $\mathrm{k}$ dosažení zamýšlených výsledků učení žáků. V českém prostředí se tomuto věnoval velmi významně Altmann (1975), který formuloval didaktické zásady výuky biologie, a právě zásadu vědeckosti uvádí na prvním místě.

Jak bylo řečeno výše, učitel má někdy sám těžkosti se zvládnutím učiva a při výuce musí ještě opravovat žáky, a to mnohdy okamžitě bez možnosti ověření si poznatku, např. v literatuře. Z analýz výukových situací vyplývá, že i zkušení učitelé často na chyby žáka nereagují, nevšimnou si jich (Pavlasová, 2017a; Jáč, 2017b). Druhá věc je, jakým zpo̊sobem na ně reagují - učitelé by měli dát ostatním žákům prostor vzniklé chyby opravit, příp. by chyby měli opravit sami (Pavlasová, 2017a).

\subsection{Oblíbenost tÉmat a motivace}

Nikdy nebyly pochybnosti o důležitosti motivace žáků. Mohou však vyvstávat potíže při uplatňování metod a přístupů, které motivaci ovlivňují (Keller, 2000). Přesto byla dovednost motivovat žáky u studentů učitelství a oborových didaktiků hodnocena jako jedna z šesti nejlépe zvládnutelných činností studentů učitelství ve výuce. Studenti učitelství tuto dovednost umístili na páté místo z nabízených 24 možností a oboroví didaktici ji umístili na místo šesté (Wernerová, 2009). K motivaci jistě může přispět i zaměření vyučovacích hodin. Rozsah, hloubka a složitost učiva vyučování lze modifikovat tak, aby výuka reagovala na potřeby, schopnosti, zájmy a přecházející znalosti žáků (Pasch, 1998), a byla tak pro žáky více motivující.

S motivací souvisí i vyučovaná témata. Oblíbenost témat/oborů přírodopisu/biologie a předmětu samotného se může lišit nejenom u pohlaví žáků, ale i mezi jednotlivými věkovými skupinami žáků. Výzkumů takto zaměřených můžeme najít více (Janštová, 2016; Kubiatko, 2012; Malcová \& Janštová, 2018; Hanzalová, 2019), problém s generalizací výsledků ale spočívá v různém výběru a velikosti vzorku respon- 
dentů. Nicméně i případové studie škol mohou přinést zajímavé výsledky jako např. nevyhraněnost názorů na oblíbenost témat u třetiny zkoumaných odpovědí (Hanzalová, 2019) nebo zmiňování neoblíbenosti geologie, a to i přes to, že tato oblast na škole, kterou zkoumaní respondenti navštěvují, není zařazena do ŠVP (Vitásek, 2017).

\section{Metodologie}

Výzkumné šetření hledalo odpovědi na následující výzkumné otázky.

Výzkumná otázka 1: Kterých oborově specifických aspektů své vyučovací hodiny prrírodopisu/biologie si studenti učitelství všímají v rámci hospitačních rozhovorů, jak je hodnotí a komentují?

Výzkumná otázka 2: Jaké jsou rozdíly ve všímání si, hodnocení i komentování oborově specifických aspektů u studentů absolvujících praxi na ZŠ a SŠ́?

\subsection{CharaKteristika ZKOUMANÉHO VZORKU A SBĚR DAT}

Respondenty výzkumného šetření byli studenti Pedagogické fakulty Univerzity Karlovy oboru Učitelství všeobecně vzdělávajících předmětů pro základní školy a střední školy - biologie $(n=35)$, kteří v rámci svého navazujícího magisterského studia absolvovali praxe na základních či středních školách.

Jednalo se o studenty, kteří si zvolili variantu praxe s pořízením videozáznamu (viz úvodní partie článku, v textu jsou označeni S1-S35). Čtrnáct z nich plnilo praxi na základní škole a dvacet jedna praxi na střední škole. V obou skupinách jsou jiní studenti. Studenti po praxi odevzdali obě reflexe a videozáznam (viz výše), který garant praxí prohlédl a připravil si podklady k hospitačnímu rozhovoru.

Z hospitačních rozhovorů byly pořízeny zvukové záznamy. Medián trvání hospitačních rozhovorů je 19 minut (nejkratší rozhovor trval 12 minut, nejdelší rozhovor trval 39 minut).

V tomto článku je analyzována jen střední část rozhovorů, kdy probíhal rozhovor strukturovaně, a otázky byly jednotné pro všechny studenty. Garant praxí kladl předem stanovené otázky zaměřené na vybrané aspekty hodiny v následujícím znění i pořadí. $V$ případě nejasné odpovědi studenta se garant praxí doptával, aby postihl smysl studentovy výpovědi. Jako první zazněla otázka na cíl a plnění cíle: 1a) Co bylo cílem výuky? 1b) Jak byl/nebyl podle vás cíl splněn a podle čeho usuzujete, že byl/nebyl cíl výuky splněn? Druhá otázka se zabývala rozsahem a obsahem učiva: 2a) Podle čeho jste zvolili rozsah učiva? 2b) Podle čeho jste volili zástupce/prezentované organizmy/jevy/pojmy? Třetí otázka zjištovala volbu pomůcek a způsob práce s učivem: 3a) Jak jste téma/zástupce demonstrovali, které pomůcky jste používali? 3b) Proč jste je demonstrovali právě tímto zpơsobem (výhody, nevýhody, alterace, predikce)? Čtvrtá otázka byla zaměřena na chyby studenta učitelství v roli učitele a chyby žáka: 4a) Jaké odborné chyby jste udělali vy? 4b) Jaké udělali žáci? Pátá otázka cílila na oblíbenost tématu a motivaci žáků: 5a) Bylo toto téma pro žáky atraktivní? 5b) Jak jste žáky motivovali ve výuce tohoto tématu?

\subsection{ZPŮSOB ANALÝZY DAT}

Hospitační rozhovory byly nejprve přepsány, následně byly rozděleny tak, aby úseky textu odrážely odpovědi na jednotlivé otázky. Tyto jednotlivé úseky byly dále kódovány dle přítomnosti (kód 1) či nepřítomnosti (kód 0) jevů v kategoriích (viz tab. 1-9). Jedna odpověd' studenta mohla být přiřazena $\mathrm{k}$ více kategoriím $\mathrm{v}$ dané 
oblasti, např. pokud student při popisu způsobu práce s učivem uvedl jeho výhody, nevýhody i alterace, byl v každé z těchto kategorií přiřazen výroku kód 1. Kódovací systém byl vytvořen pro účely výzkumu. Při stanovování kategorií jsme vycházeli z výpovědí studentů, kdy výrokům studentů byly přiřazeny kódy vystihující jejich povahu nejdříve ad-hoc a posléze byly přejmenovány, zpřesňovány, případně slučovány (Hendl, 2005; Švařriček \& Šed’ová, 2007). Postupně vznikly kategorie uvedené v tab. 1-9. U vybraných kategorií, kde jsme se dotazovali na zdůvodnění studentova stanoviska, byla posuzována i kvalita odpovědi studenta ve dvou úrovních (laický výrok a erudovaný výrok). Vzhledem $\mathrm{k}$ tomu, že erudovaných výroků (řádně vysvětlených, případně i s využitím teorie) bylo ve výrocích minimum, v tabulkách ve výsledcích jsou uvedeny jen výroky laické. Erudované výroky jsou potom zmíněny jen pomocí slovního komentáře, podobně jako málopočetně zastoupené kategorie. Např. odpověd’ na otázku 1a) „Co bylo cílem výuky?" studenta S1: „Rozlišit mitózu od miózy a vysvětlit, proč je to důležité." byla kódována u kategorie použivá aktivní slovesa: 1, formulace pomocí obsahu učiva: 1, uvede cíle v kognitivní oblasti: 1, zbylé kategorie: 0.

Postupné kódování bylo procesem spolupráce dvou výzkumníků, kdy docházelo k úpravám a vzájemné kontrole hodnocení kódů cyklicky celkem $4 \times$. Výsledný kód byl přiřazen po vzájemné dohodě a to na základě diskuse a shody obou kódujících. K hodnocení dat byl použit MS Excel.

\section{VÝSLEDKY}

\subsection{CÍle VÝUKY}

V odpovědích na otázku „Co bylo cílem výuky?" většina respondentů (celkem $88,57 \%$ studentů) cíle formulovala pomocí obsahu učiva, např. „Cílem výuky byly prvohory, druhohory a třetihory" S12, což považujeme za přetrvávající nešvar výukové praxe. Pouze necelá polovina respondentů pro formulaci cílů používala tzv. „aktivní slovesa“ ( CĆ́lem bylo, aby dokázali popsat jednotlivé biomy světa a dokázali je správně charakterizovat a zařadit." S28), studenti s praxí na SS̆ v trochu větší míře než studenti s praxí na ZŠ. Cíle byly v převážné většině odpovědí uváděny v oblasti kognitivní, a to častěji studenty, kteří byli na praxích na ZŠ než na SS̆ s poměrně velkým rozdílem. Afektivní cíle byly uvedeny pouze ve dvou případech (prevence onemocnění a zdravý životní styl u učiva o biologii člověka, S31 a S14), a to vždy u studentů praktikujících na SS̆, psychomotorické cíle respondenti nezmiňovali vůbec. Protože se jednalo o vyučovací hodiny ve tř̌́dě, a ne laboratorní cvičení či exkurze, je to v tomto př́padě pochopitelné. Procentuální vyjádření odpovědí je možné spatřit $\mathrm{v}$ tab. 1 . Pouze $\mathrm{v}$ jednom př́padě student pro svou výuku formuloval i rozvoj komunikativní kompetence, ke které mělo při výuce docházet využitím diskuse (S7).

Tab. 1: Cíle výuky

\begin{tabular}{|c|c|c|c|c|c|c|}
\hline \multirow[t]{2}{*}{ Praxe na } & \multicolumn{2}{|c|}{$\begin{array}{l}\text { Formulace pomocí } \\
\text { obsahu učiva }\end{array}$} & \multicolumn{2}{|c|}{ Aktivní slovesa } & \multicolumn{2}{|c|}{ Kognitivní cíl } \\
\hline & abs. & rel. & abs. & rel. & abs. & rel. \\
\hline$\overline{\mathrm{ZS}}(n=14)$ & 12 & $85,7 \%$ & 6 & $42,9 \%$ & 10 & $71,4 \%$ \\
\hline$\overline{\mathrm{SS}}(n=21)$ & 19 & $90,5 \%$ & 10 & $47,6 \%$ & 10 & $47,6 \%$ \\
\hline Celkem $(n=35)$ & 31 & $88,6 \%$ & 16 & $45,7 \%$ & 20 & $57,1 \%$ \\
\hline
\end{tabular}


V navazující otázce měli studenti uvést, zda byl/nebyl podle nich cíl splněn a podle čeho usuzují, že byl/nebyl cíl výuky splněn, viz tab. 2. Při praxi na základní škole se dva respondenti vůbec nedokázali vyjádřit $\mathrm{k}$ tomu, zda byl cíl jejich výuky splněn nebo ne. Při praxi na střední škole, která probíhá v jejich studiu jako druhá v pořadí, se k plnění cíle již vyjádřili všichni.

Tab. 2: Splnění cílů a jejich kontrola

\begin{tabular}{|c|c|c|c|c|c|c|c|c|}
\hline \multirow[t]{2}{*}{ Praxe na } & \multicolumn{2}{|c|}{ Plnění cíle } & \multicolumn{2}{|c|}{$\begin{array}{c}\text { Kvalita } \\
\text { zdůvodnění }\end{array}$} & \multicolumn{2}{|c|}{$\begin{array}{c}\text { Popis } \\
\text { kontroly } \\
\text { cíle }\end{array}$} & \multicolumn{2}{|c|}{$\begin{array}{l}\text { Zdůvodnění } \\
\text { výběru } \\
\text { kontroly cíle }\end{array}$} \\
\hline & abs. & rel. & abs. & rel. & abs. & rel. & abs. & rel. \\
\hline$\overline{\mathrm{ZS}}(n=14)$ & 12 & $85,7 \%$ & 9 & $64,3 \%$ & 10 & $71,4 \%$ & 1 & $7,1 \%$ \\
\hline$\overline{\mathrm{SS}}(n=21)$ & 21 & $100,0 \%$ & 18 & $85,7 \%$ & 17 & $81,0 \%$ & 1 & $4,8 \%$ \\
\hline Celkem $(n=35)$ & 33 & $94,3 \%$ & 27 & $77,1 \%$ & 27 & $77,1 \%$ & 2 & $6,1 \%$ \\
\hline
\end{tabular}

Zdůvodnit, podle čeho poznali, že byl cíl splněn, dokázalo při praxi na základní škole $64,29 \%$, zatímco na střední škole $85,71 \%$, to však pouze na laické úrovni. Plnění cíle respondenti nezdůvodňovali erudovaně, dokonce ani nevysvětlovali volbu právě tohoto cíle a při hodnocení splnění cíle se neopírali o žádnou z didaktických či pedagogických teorií. Typické vyjádření respondentů, kteří nedokázali ani laicky zdůvodnit plnění cíle akceptovatelně pro garanta praxí, znělo většinou takto: „Všechno jsme si řekli a také jsme opakovali." S1 nebo „Prošli jsme, myslím, tři skupiny a děti si stihly udělat zápisky právě od těchto skupin a mají podklady dál." S10. Většina respondentů $(77,14 \%)$ byla schopna uvést, jakým zpo̊sobem kontrolovali, zda a v jaké míře ke splnění cíle u žáků došlo, přičemž četnost uvedeného popisu kontroly cíle mírně převažovala u studentů vykonávajících praxi na SS̆.

Zdůvodnění toho, z jakého důvodu respondenti kontrolovali dosažení cílů právě zvoleným zpo̊sobem, uvedli pouze dva studenti. Jako př́íklad uvádíme výpověd’ studentky učící na základní škole:

$\mathrm{Na}$ základě toho že se v tom orientují, že si dokážou savce zařadit do těch rozdělených skupin. Osvědčilo se mi to a strašně se mi líbilo to, že na konci každé výkladové hodiny, když se stihne probrat celá ta látka, tak 5 minut před koncem hodiny si žáci dávaji z látky otázky. To bylo hezké a převezmu si to. A z toho já vidím, jestli ví nebo neví. To jsem dělala $v$ paralelni tř́dě a tam bylo vidět, že holka dala otázku a nevěděla, na co se ptá, špatně to položila. A vuibec to neuměla vysvětlit. Takže tady jsem udělala chybu, že jsem to špatně vysvětlila. To byla 1. tř́da a potom jsem si to uvědomila a jinak jsem to zpracovala $v$ té 2. tř́dě a tam se to podařilo. S32

\subsection{OBSAH A ROZSAH UČIVA}

Otázka „Podle čeho jste zvolili rozsah učiva?“ poukazuje na materiály, příp. zdroje, ze kterých studenti čerpají učivo, jež svým žákům předávají. Jak je patrné z tab. 3, celkově nejčastěji jsou tímto zdrojem právě fakultní učitelé, kteří studentům rozsah učiva sdělí. To se neliší v průběhu praxe na ZŠ a na SS̆. U studentů působících na ZŠ jsou nejčastějším zdrojem rozsahu učiva učebnice. Učebnice jsou i druhou nejčastější volbou u studentů působících na praxi na SS̆. Třetí nejčastěji volenou 
variantou studentů působících jak na ZŠ i SS̆ jsou vlastní zkušenosti, pocity a odhad studentů. Ani zde se obě skupiny studentů nelišily.

Nejméně volenými variantami jsou volba rozsahu učiva podle ŠVP a podle výuky na VS̆, kterou studenti absolvovali. První možnost byla uvedena jedním studentem učícím na základní škole (S9), druhá možnost jedním studentem konajícím praxi na SS̆ (S2).

Tab. 3: Volba rozsahu učiva

\begin{tabular}{|c|c|c|c|c|c|c|}
\hline \multirow[t]{2}{*}{ Praxe na } & \multicolumn{2}{|c|}{$\begin{array}{c}\text { Podle sebe, } \\
\text { své zkušenosti, } \\
\text { svého pocitu, } \\
\text { odhadem }\end{array}$} & \multicolumn{2}{|c|}{$\begin{array}{c}\text { Podle } \\
\text { učebnice }\end{array}$} & \multicolumn{2}{|c|}{$\begin{array}{l}\text { Podle fakultního } \\
\text { učitele/výuky } \\
\text { obvyklé na škole }\end{array}$} \\
\hline & abs. & rel. & abs. & rel. & abs. & rel. \\
\hline$\overline{\mathrm{ZS}(n=14)}$ & 6 & $42,9 \%$ & 12 & $85,7 \%$ & 11 & $78,6 \%$ \\
\hline$\overline{\mathrm{SS}}(n=21)$ & 8 & $38,1 \%$ & 12 & $57,1 \%$ & 16 & $76,2 \%$ \\
\hline Celkem $(n=35)$ & 14 & $40,0 \%$ & 24 & $68,6 \%$ & 27 & $77,1 \%$ \\
\hline
\end{tabular}

V následující otázce se garant praxí ptal již cíleně, aby si případně potvrdil odpovědi z předchozí otázky na to, podle čeho studenti volili zástupce/prezentované organizmy/jevy/pojmy. K této otázce se studenti nebyli schopni až na některé výjimky téměř vůbec vyjádřit, což vidíme z nízkého počtu odpovědí v tab. 4. Při výběru zástupců, jevů a pojmů pro výuku se studenti, kteří během své praxe učili na ZS̆, nejčastěji inspirovali $\mathrm{v}$ učebnicích či pro výuku ve stejném počtu př́padů použili vlastní zkušenosti, pocity a odhad („Já jsem se rozhodl, že vyberu více zástupců než je potřeba, abych žákům ukázal diverzitu obojživelníků u nás." S9, „Zástupce jsem volila také podle toho, co mi přišlo, že děti mohou nejběžněji znát a s čím se mohou potkat." S10, "Zástupce jsem volila s ohledem na roční období, protože bylo jaro a květ tulipánu byl nejsehnatelnější i v obchodě." S20). Studenti, kteří praxe na ZŠ již absolvovali a nyní působili jako učitelé na SS̆, v odpovědích již neuváděli žádné podstatné informace. Dva používali učebnici a dále pak byl zastoupen jeden komentář o volbě zástupců, jevů a pojmů pro vyučovací hodinu na základě konzultace s vyučující v dané třídě.

Tab. 4: Volba zástupců/prezentovaných organismů/jevů/pojmů

\begin{tabular}{|c|c|c|c|c|c|c|}
\hline \multirow[t]{2}{*}{ Praxe na } & \multicolumn{2}{|c|}{$\begin{array}{c}\text { Podle sebe, } \\
\text { své zkušenosti, } \\
\text { svého pocitu, odhadem }\end{array}$} & \multicolumn{2}{|c|}{ Podle učebnice } & \multicolumn{2}{|c|}{$\begin{array}{l}\text { Podle fakultního } \\
\text { učitele/výuky } \\
\text { obvyklé na škole }\end{array}$} \\
\hline & abs. & rel. & abs. & rel. & abs. & rel. \\
\hline$\overline{\mathrm{ZS}(n=14)}$ & 4 & $28,6 \%$ & 4 & $28,6 \%$ & 0 & $0,0 \%$ \\
\hline$\overline{\mathrm{SS}(n=21)}$ & 0 & $0,0 \%$ & 2 & $9,5 \%$ & 1 & $4,8 \%$ \\
\hline Celkem $(n=35)$ & 4 & $11,4 \%$ & 6 & $17,1 \%$ & 1 & $2,9 \%$ \\
\hline
\end{tabular}

\subsection{POMŮCKY A ZPŮSOB PREZENTACE UČIVA}

Mezi nejčastější pomůcky, které respondenti při otázce „Jak jste téma/zástupce demonstrovali, které pomůcky jste používali?", viz tab. 5, patřila především prezentace a interaktivní tabule. Důvodem volby právě těchto pomůcek je snaha o názornost, jak uvádí např. studentka S3: „Myslím si, že to výhody určitě má, protože obrázky 
Tab. 5: Pomůcky využité k demonstraci tématu/zástupců

\begin{tabular}{|c|c|c|c|c|c|c|c|c|}
\hline \multirow[t]{2}{*}{ Praxe na } & \multicolumn{2}{|c|}{$\begin{array}{c}\text { Obrázky, } \\
\text { plakát }\end{array}$} & \multicolumn{2}{|c|}{ Model } & \multicolumn{2}{|c|}{$\begin{array}{l}\text { Animace, } \\
\text { video }\end{array}$} & \multicolumn{2}{|c|}{ Přírodnina } \\
\hline & abs. & rel. & abs. & rel. & abs. & rel. & abs. & rel. \\
\hline$\widetilde{\mathrm{ZS}}(n=14)$ & 9 & $64,3 \%$ & 0 & $0,0 \%$ & 2 & $14,3 \%$ & 3 & $21,4 \%$ \\
\hline$\overline{\mathrm{SS}}(n=21)$ & 11 & $52,4 \%$ & 3 & $14,3 \%$ & 4 & $19,0 \%$ & 2 & $9,5 \%$ \\
\hline Celkem $(n=35)$ & 20 & $57,1 \%$ & 3 & $8,6 \%$ & 6 & $17,1 \%$ & 5 & $14,3 \%$ \\
\hline \multirow[t]{2}{*}{ Praxe na } & \multicolumn{2}{|c|}{$\begin{array}{l}\text { Prezentace, } \\
\text { interaktiv. } \\
\text { tabule }\end{array}$} & \multicolumn{2}{|c|}{$\begin{array}{l}\text { Prac. list, } \\
\text { kř́lžovka, } \\
\text { text }\end{array}$} & \multicolumn{2}{|c|}{ Učebnice } & \multicolumn{2}{|c|}{ Jiné } \\
\hline & abs. & rel. & abs. & rel. & abs. & rel. & abs. & rel. \\
\hline$\overline{\mathrm{ZS}}(n=14)$ & 10 & $71,4 \%$ & 7 & $50,0 \%$ & 3 & $21,4 \%$ & 8 & $57,1 \%$ \\
\hline$\overline{\mathrm{SS}}(n=21)$ & 17 & $81,0 \%$ & 8 & $38,1 \%$ & 2 & $9,5 \%$ & 5 & $23,8 \%$ \\
\hline Celkem $(n=35)$ & 27 & $77,1 \%$ & 15 & $42,9 \%$ & 5 & $14,3 \%$ & 13 & $37,1 \%$ \\
\hline
\end{tabular}

vidí celá třída najednou, jsou velké a jsou hezky vidět. Kdybych jim to jenom popisovala, tak by si to nedokázali tolik představit."

Prezentace byla dále volena i z důvodu usnadnění výuky pro samotné respondenty, viz komentář studentky S4: „Protože si myslím, že i pro mě je pohodlnější mít prezentaci než psát výklad na tabuli, kdy pak kolikrát nemám přehled o tom, co se děje ve třídě." nebo komentář studentky S24:

Mě to takhle, poměrně, vyhovuje. Já jsem na to zvyklá z té základní školy, že mám vždy připravené nějaké ty prezentace, o které se opírám a pomáhá mi to $i$ při tom samotném výkladu, že třeba na něco nezapomenu nebo nevynechám.

Mezi další důvody patřilo i zvýšení zájmu u žákio, jak je patrné z odpovědi studentky S22: „Přinesla jsem si ten muškát, čímž jsem se snažila žáky zaujmout.“, a názornost výuky, jak je uvedeno v komentáři studentky S10:

Zaprvé proto, že dataprojektor s tabuli byl $k$ dispozici a také proto, že mi to přijde pro děti přistupnější z hlediska moderní technologie. Všichni hned vidi obrázky najednou, takže nemusi kolovat a mám jistotu, že všichni zrovna vidí to, co chci, aby viděli, a nekoukají někam jinam.

Názornost výuky je také zahrnuta v odpovědi studentky S12:

Snažila jsem se tam právě dávat více pomůcek a metod. Snažila jsem se tam na konci, já se teda přiznám, nevím, jestli jste si všimla, že jsem tam měla asi tři minutky do konce, tak jsem tam dala ještě jednu hru, kde tam měli vyjmenovat všechny ty zástupce, co jsme si jmenovali. Videohru a ty pomůcky mi nabídla paní profesorka, já jsem totiž nevěděla, že je tam mají, v té tř́dě jsem nebyla. Toho jsem využila.

Na základních i středních školách byly druhou nejčastější používanou pomůckou obrázky a plakáty.

Jako nejméně využívanými pomůckami byly na ZŠ uváděny přírodnina a učebnice (využili 3 studenti), dále animace a videa (využili 2 studenti) a model (nevyužil ani 
1 student). Na SŠ mezi nejméně používané pomůcky patřila animace a video (využili 4 studenti), model (využili 3 studenti), př́rodnina a učebnice (využili 2 studenti). Mezi další pomůcky, které byly zařazeny do kategorie Jiné, byla dvakrát zmíněna tabule a myšlenková mapa. Dále pak studenti vždy po jednom uváděli např. počítač s internetem, časopis, didaktickou hru domino, odbornou knihu, dále pak váhu, tlakoměr či švihadlo, které bylo použito pro znázornění biologického procesu.

Z odpovědí na otázku dále vyplynuly některé další informace, jako např. které metody, př́íp. postupy, studenti nejčastěji volili (garant praxí se na ně dále nedoptával, takže vyjádření nebylo získáno od všech studentů). Nejčastěji se jednalo o metody výkladu, dále pak o vyprávění, demonstraci plakátu (modelu), induktivní metodu, brainstorming, diskusi, řízený rozhovor, práci s textem, samostatnou práci a didaktickou hru. Ani jednou nebyla zmíněna badatelsky orientovaná výuka.

Dále měli studenti zdůvodnit, proč demonstrovali učivo právě tímto způsobem a garant praxí se cíleně doptával na výhody, nevýhody, alterace a predikce tohoto postupu. Z tab. 6. je patrné, kolik procent respondentů uvedlo zdůvodnění, výhody a nevýhody demonstrace vybraným způsobem. Zdůvodnění bylo nejčastěji laické a nepodložené argumenty („Já myslím, že je to nejkomfortnější.“ S5, „Myslím si, že zrovna ty obrázky jsou dostačující asi, myslím si, že vycpanýho papouška bych si nepřinesla." S6)

Po zhlédnutí videa někteří studenti považovali za chybu, že si připravili výuku s minimálním vynaložením úsilí ( „On je to vlastně nejjednodušší způsob, jak vytvořit hodinu, ale když jsem viděla toto video, tak mě to mrzelo, protože si myslím, že by se to dalo udělat lépe." S11).

Také uvádění výhod a nevýhod zvoleného způsobu demonstrace učiva bylo často didakticky nepropracované („Pro mě bylo jednodušší, že jsem nemusela živočichy složitě popisovat, jen bylo potřeba ukázat obrázek a k tomu říct příslušné rysy." S27, „Musela jsem chodit pořád překlikávat, protože tam nebyl dálkový ovladač na tu prezentaci, tudíž jsem nemohla procházet celou tu tř́du." S22) Našli se ale i respondenti, jejichž výpovědi svědčí o hlubším uvažování o své výuce.

Výhody to má určitě, když je kost nakreslená, tak je plochá, takže když jsem přinesla celou pánev do hodiny, tak se mohla různě otočit, mohli si ji omotat a přsně vidět, kde dolík je, na tom obrázku se to relativně špatně ukazuje. S30

Já si myslím, že nevýhoda je tam hlavně ta kázeñ těch dětí, když pracuji ve skupinkách, že je potřeba hodně dbát na to, aby pracovaly a aby nepracovali dva $v$ té skupince a ostatni si jen povídali, tak aby opravdu spolupracovala celá ta skupinka. S13

Důležité je, že si respondenti uvědomovali klady i zápory jimi zvolených způsobů demonstrace, jak je patrné z komentářu studentek S4 a S14:

Pro mě je až moc dopředu daná výuka. Já vím, že by měla být naplánovaná, ale někdy se může ta hodina vyvrbit jinak, že začne třeba nějaká diskuze, kde chce žák něco vyprávět. A proto když jsou ty slajdy jasně nalinkovaný, tak já už je nemůžu změnit v průběhu té hodiny. Nebo když mám v prezentaci nějakou chybu. Třeba když si stáhnu špatný obrázek, tak to v prüběhu hodiny prostě nezměním.

Myslím si, že ta prezentace neni úplně nutná. Poradila jsem si $i$ bez toho, $k d y \check{z}$ mi to nefungovalo. Myslím, že ne vždy je dobré tu prezentaci použivat. Proč myslíte (doplňujíci otázka garanta praxí)? Lidi maji tendenci 
sledovat tu prezentaci a ten člověk má tendenci říkat to, co už je na v té prezentaci. Žáci si to opisuji a nejsme potom v tom kontaktu. Prezentace nemám moc osobně ráda. Nevím, jestli je to správně, ale třeba $v$ té biologii bych volila jiný př́stup.

Velká část respondentů ke svým způsobům demonstrace nabídla i jinou alternativu. V některých př́ípadech studenti alternativu sice nabídli, ale vzápětí uvedli důvod nevhodnosti zařazení jako v případě výpovědi studentky S3: „Mohla bych je přinést do výuky (živé exponáty). Myslím si, že by je to více zaujalo, ale narušilo by to hodinu, protože by se zviŕata musela nechat kolovat a dávali by menší pozor."

U některých respondentů dokonce došlo k uvědomění si vhodnosti alternativního způsobu demonstrace jako u studentky S8:

Určitě by bylo dobré, kdybych měla živočichy $k$ dispozici př́mo na demonstraci. A proč? Protože by žáci viděli nějakou realitu. Takto vlastně, když to člověk vidí jen na obrázku nebo na prezentaci, tak třeba nemá tu správnou výbavu si to představit. Samozřjmě k nějakému osahání by tam nemohlo dojít, takže spíš jako jen vizuální vjem.

Predikce se týkaly převážně vlivu výuky na zapamatování učiva: „Myslím si, že když si obrázek překreslovali do sešitu, tak si to lépe zapamatují, znám to z vlastní zkušenosti, protože profesor na střední škole kreslil všechno výhradně na tabuli, a když jsem se to zpětně učila, tak jsem si to pamatovala lépe." S34

„Kdybych jim o tom jenom vyprávěla a ukázala obrázky, tak potom půjdou do lesa a nespojí si to s tím, ale takhle když ten mech drží v té ruce, tak si vzpomenou, jak jsem jim to tu ukazovala." S25

Pokud studenti byli dotazování, většinou byli schopni nějakou alternativu svého výukového postupu uvést (viz tab. 6). Zajímavý je fakt, že větší počet studentů, kteří nabízeli alterace a predikce, byli studenti působící během své praxe na ZS̆.

Tab. 6: Vysvětlení způsobu demonstrace učiva

\begin{tabular}{lcccccccccr}
\hline Praxe na & \multicolumn{2}{c}{ Zdůvodnění } & \multicolumn{2}{c}{ Výhody } & \multicolumn{2}{c}{ Nevýhody } & \multicolumn{2}{c}{ Alterace } & \multicolumn{2}{c}{ Predikce } \\
& abs. & rel. & abs. & rel. & abs. & rel. & abs. & rel. & abs. & \multicolumn{1}{c}{ rel. } \\
\hline $\mathrm{ZS}(n=14)$ & 10 & $71,4 \%$ & 12 & $85,7 \%$ & 6 & $42,9 \%$ & 12 & $85,7 \%$ & 3 & $21,4 \%$ \\
\hline $\mathrm{S} \breve{S}(n=21)$ & 14 & $66,7 \%$ & 17 & $81,0 \%$ & 12 & $57,1 \%$ & 17 & $81,0 \%$ & 2 & $9,5 \%$ \\
\hline Celkem $(n=35)$ & 24 & $68,6 \%$ & 29 & $82,9 \%$ & 18 & $51,4 \%$ & 29 & $82,9 \%$ & 5 & $14,3 \%$ \\
\hline
\end{tabular}

\subsection{Chyby STUDENTU゚ UČITELSTVí V ROLI UČITELE A CHYBY ŽÁKŮ}

Garant praxí se nejprve dotazoval, jaké odborné chyby udělali studenti v roli vyučujícího. Jen necelá polovina všech respondentů byla schopna uvést konkrétní příklady chyb, kterých se během vyučování dopustili, viz tab. 7. Studenti, kteří působili na praxi na ZŠ, uváděli výčet svých chyb častěji než studenti působící na SS̆. Konkrétní chyby respondentů lze rozdělit do několika skupin. Jedná se např. o odbornou chybu (6 studenti̊ na ZŠ, tj. 42,86 \%, 4 studenti na SS̆, tj. 19,05 \%), organizační chybu (2 studenti na ZS a 4 studenti na SS̆), nepřesnou/neúplnou formulaci odpovědí při zaskočení dotazem od žáků (1 student na ZŠ a 1 student na SŠ), přeřeknutí (3 studenti na ZŠ a 3 studenti na SŠ), zapomínání uvedení a vybavení si informací 
z důvodu nervozity, hledání pomůcek (1 student na ZŠ a 2 studenti na SŠ), neznalost jmen žáků (2 studenti na SS̆), gramatická chyba na tabuli (1 student na SS̆). Někteří studenti uváděli, že chybu udělali, ale nebyli schopni uvést jakou. V tab. 7 je uvádíme jako obecné chyby.

Tab. 7: Chyby studentů učitelství v roli učitele

\begin{tabular}{lcccc}
\hline Praxe na & \multicolumn{2}{c}{ Konkrétní chyba } & \multicolumn{2}{c}{ Obecná chyba } \\
& abs. & rel. & abs. & rel. \\
\hline Z $\breve{S}(n=14)$ & 9 & $64,3 \%$ & 1 & $7,1 \%$ \\
\hline ŠS $(n=21)$ & 8 & $38,1 \%$ & 4 & $19,0 \%$ \\
\hline Celkem $(n=35)$ & 17 & $48,6 \%$ & 5 & $14,3 \%$ \\
\hline
\end{tabular}

Na otázku zjištujujicí chyby učitele navazovala otázka na chyby, které udělali žáci. Studenti působící na praxi na ZŠ i SS̆ až na jednu výjimku nereflektovali vůbec žádné chyby žáků během vyučovací hodiny. Zmíněný student (S28) uvedl, že: „Když žáci řekli něco špatně, tak jsem se nad tím s nimi pozastavil, snažil jsem se jim to vysvětlit." V ostatních komentářích se studenti vyjadřovali pouze k chybám, kterých se sami dopouštěli.

\subsection{Oblíbenost témat a motivace}

Garant praxí dále zjištoval, zda se studenti učitelství domnívají, že jimi vyučované téma bylo pro žáky atraktivní. Na základě jejich odpovědi poté zjištoval, zda tento svůj názor nějak zohlednili při motivaci žáků. Z tab. 8 je patrné, že celkem 16 respondentů se domnívá, že téma, které bylo předmětem vyučování, bylo pro žáky zajímavé a atraktivní. Témata dle pohledu studentů pro žáky nezajímavá byla učena ve 12 vyučovacích hodinách a 7 studentů nevědělo, jak by téma žáci hodnotili. Zdůvodnění, resp. vysvětlení, svého názoru na atraktivitu tématu uvedlo 13 respondentů.

Tab. 8: Atraktivita témat pro žáky

\begin{tabular}{lrrrrrrrr}
\hline Praxe na & \multicolumn{2}{c}{ Ano } & \multicolumn{2}{c}{ Ne } & \multicolumn{2}{c}{ Neví } & \multicolumn{2}{c}{ Zdůvodnění } \\
& abs. & rel. & abs. & rel. & abs. & rel. & abs. & rel. \\
\hline $\mathrm{ZS}(n=14)$ & 8 & $57,1 \%$ & 3 & $21,4 \%$ & 3 & $21,4 \%$ & 4 & $28,6 \%$ \\
\hline S⿱ $(n=21)$ & 8 & $38,1 \%$ & 9 & $42,9 \%$ & 4 & $19,0 \%$ & 9 & $42,9 \%$ \\
\hline Celkem $(n=35)$ & 16 & $45,7 \%$ & 12 & $34,3 \%$ & 7 & $20,0 \%$ & 13 & $37,1 \%$ \\
\hline
\end{tabular}

Nicméně pouze tři studenti uvedli své zdůvodnění erudovaně či se při vysvětlování opírali o existující teorie, na základě kterých by svá konstatovaní potvrdili. Všichni zmiňují spojení učiva s praxí. Např. studentka S13 uvedla, že:

Já si myslím, že ano (̌̌e je téma zajímavé pro žáky), protože třeba vím, co s nimi probíral kolega včelu, tak to je velice zajímavá výroba medu. Mravenci mají, jak jsou vlastně chráněná mraveniště, tak to je zajímalo. Takové praktické využití jako komáři a malárie a tak. To je bavilo.

Studentka S24 uvedla: „Já si myslím, že ano (že je téma zajímavé pro žáky). Baví je to v podstatě ze života, že to téma mají do jisté míry osahané."

Zajímavé je vnímání stejných nebo podobných témat, kde studenti v některých případech hodnotili téma jako zajímavé pro žáky, zatímco v jiných případech tomu bylo naopak. Jedná se např. o téma rostliny. Z celkového počtu 6 vyučovacích hodin 
s touto tematikou, hodnotili 4 studenti téma jako neoblíbené. Dva studenti téma hodnotili naopak jako oblíbené. Dokonce zcela totožné téma bylo studenty vnímáno zcela opačně z hlediska oblíbenosti u žáků. Jednalo se o téma rostlinná pletiva.

Zoologická témata jsou většinou z hlediska předpokládané oblíbenosti mezi žáky hodnocena pozitivně až na výjimky, jako je např. úvod do zoologie. Téma hmyz bylo studenty učitelství vnímáno rozporuplně. Témata spojená s problematikou lidského těla byla hodnocena pozitivně $\mathrm{z}$ hlediska oblíbenosti u žáků především v př́ípadech, kdy již z názvu tématu bylo zřetelné, že se jedná o problematiku spojenou se skutečným životem žáků, jako jsou např. civilizační onemocnění, onemocnění oběhové soustavy, př́p. první pomoc. Pokud byla témata z oblasti orgánových soustav a genetiky, byla studenty učitelství hodnocena jako nezajímavá pro žáky.

Po uvědomění si, zda bylo téma atraktivní pro žáky či ne, následovala otázka, jak v roli učitele žáky motivovali ve výuce tohoto tématu. Dle tab. 9 mezi nejčastější formy motivace patří názornost pomocí obrázků a videí, dále pak aktivizace žáků a jiné formy motivace. Jedná se např. o volbu výukových metod a pomůcek. Studentka S10 uvedla:

Jednak to, jakým způsobem byla hodina pojatá. Bylo to netradiční, takže o to víc tam byl efekt zapojenosti. Potom taky exemplář co přinesla žákyně, takže si myslím, že právě tím to bylo zajímavé.

Dále se jedná o sdělování zajímavostí: „Vlastně využíváním těchto zajímavostí jsem se snažil, aby dávali pozor a zajímalo je to." S9 a zdůrazňování důležitosti tématu: „V úvodu jsem dost zdůrazňoval, pro co je téma důležitý." S1.

Tab. 9: Způsob motivace žáků ve výuce

\begin{tabular}{|c|c|c|c|c|c|c|c|c|c|c|}
\hline \multirow[t]{2}{*}{ Praxe na } & \multicolumn{2}{|c|}{$\begin{array}{c}\text { Názornost, } \\
\text { video, } \\
\text { obrázky }\end{array}$} & \multicolumn{2}{|c|}{$\begin{array}{l}\text { Aktivizace } \\
\text { žáka }\end{array}$} & \multicolumn{2}{|c|}{ Př́rodnina } & \multicolumn{2}{|c|}{$\begin{array}{c}\text { Spojení } \\
\text { s praxí/ } \\
\text { praktické } \\
\text { úkoly nebo } \\
\text { ukázky }\end{array}$} & \multirow{2}{*}{\multicolumn{2}{|c|}{ Jiné }} \\
\hline & abs. & rel. & abs. & rel. & abs. & rel. & abs. & rel. & & \\
\hline$\overline{\mathrm{ZS}}(n=14)$ & 3 & $21,4 \%$ & 5 & $35,7 \%$ & 2 & $14,3 \%$ & 1 & $7,1 \%$ & 3 & $21,4 \%$ \\
\hline$\overline{\mathrm{SS}}(n=21)$ & 7 & $33,3 \%$ & 3 & $14,3 \%$ & 2 & $9,5 \%$ & 3 & $14,3 \%$ & 5 & $23,8 \%$ \\
\hline$\overline{\text { Celkem }(n=35)}$ & 10 & $28,6 \%$ & 8 & $22,9 \%$ & 4 & $11,4 \%$ & 4 & $11,4 \%$ & 8 & $22,9 \%$ \\
\hline
\end{tabular}

\section{DiskUSE}

Pomocí hospitačních rozhovorů se zpravidla snažíme působit na rozvoj profesního vidění u studentů tak, aby se zaměřovali především na oborově specifické jevy. Z publikovaných údajů je zřejmé, že právě ty bývají studenty učitelství opomíjeny (Pavlasová, 2017b; Pavlasová et al., 2018). Hospitační rozhovor měl v našem př́ípadě nestrukturovanou i strukturovanou část, kdy strukturovaná část se skládala z otázek stejných pro všechny studenty na praxích a $\mathrm{z}$ otázek zaměřených na jevy v hodině vždy u konkrétního studenta. V dalším textu jsou diskutovány odpovědi na společné otázky, které byly předmětem námi provedeného šetření. Otázka „Co bylo cílem výuky?" byla zkoumána z hlediska používání aktivních sloves, formulace pomocí obsahů učiva a rozvoje zamýšlených kompetencí při stanovení cíle. Z našeho výzkumu je patrné, že celých 88,57 \% výukových cílů bylo v rámci hospitačních rozhovorů definováno právě pomocí obsahu učiva. Obdobná situace byla zjištěna 
i ve výzkumu Staré a Starého (2018), při kterém učitelé přímo ve vyučovací hodině namísto sdělení výukových cílů také často žákům sdělovali pouze téma hodiny nebo často i metody či postupy práce. S ohledem na studii Janíka (2007) je zaměňování cílů vyučovací hodiny s informacemi o obsahu velmi časté (osm z jedenácti respondentů cíle výuky zaměňuje právě za sdělení obsahu). Dle Skalkové (2007) se jedná o chybu, ke které v praxi dochází nezřídka kdy. Obsah vyučovací hodiny může být také někdy záměrně zatajen, a to z důvodu probuzení zvídavosti a zájmu u žáků (Stará \& Starý, 2018).

Používání aktivních sloves je patrné pouze u necelé poloviny respondentů, což je opět doklad jedné z častých chyb stanovování výukových cílů dle Mazáčové (2014).

Respondenti dále uváděli cíle, které žáky rozvíjely především v kognitivní oblasti, přitom zapomínali na rozvoj v ostatních oblastech - psychomotorické a afektivní. Navíc, dle studie Sultana (1999), je 43,3 \% výukových cílů u začínajících učitelů do jednoho roku praxe tvořeno nejnižším kognitivním stupněm Bloomovy taxonomie.

Dle Skalkové (2007) termín kompetence (klíčové kompetence) souvisí s rozvojem žáků, a to právě ve smyslu definovaných cílů. V našem výzkumném šetření však zmínění kompetencí při definování výukových cílů bylo zaznamenáno pouze v jednom př́padě.

Odpovědí na otázku, zda byl/nebyl podle studentů cíl splněn a podle čeho tak usuzují, by při správném stanovení pomocí aktivních sloves mělo být možné dohledat již ve výukovém cíli samotném. Správně definovaný výukový cíl má totiž obsahovat kromě požadovaného výkonu žáků (co má žák umět vykonat) i kritéria hodnocení. Učitelé poté mohou posoudit, zda žák stanoveného cíle dosáhl či naopak (Pasch, 1998; Švec, Filová \& Šimoník, 2004).

Jak již bylo zmíněno, respondenti při stanovení cílů aktivní slovesa používali pouze v necelé polovině př́ípadů. Své odpovědi na otázku, jakým způsobem respondenti usuzovali, že byl cíl splněn, někteří z nich formulovali jen velmi obecně.

Z některých odpovědí je patrné, že nutně neznamená, že respondent, který pro stanovení cíle použije správně aktivní slovesa, vede činnosti během výuky opravdu v souladu s cílem a že dosažení cíle v souladu se svým původně stanoveným cílem také ověřuje. Pozorujeme zde tzv. nekonzistentnost cíle, vyučovacích činností a postupů při hodnocení dosažených cílů v praxi (Pasch, 1998).

Pokud by byly cíle definovány jasně již na začátku vyučovací hodiny, učitel by po celou dobu výuky mohl společně $\mathrm{s}$ žáky $\mathrm{k}$ cíli směřovat a na závěr byl mohl ověřit, zda k naplnění cíle opravdu došlo. Dle výzkumu (Stará \& Starý, 2018) respondenti cíle, resp. očekávané znalosti a dovednosti, ve velké míře však vůbec svým žákům nesdělují. Pouze ve dvou př́padech z deseti vyučující sdělila poměrně konkrétní informace o tom, co je záměrem vyučovací hodiny. Vysoká míra explicitnosti je tedy spojena s jasností. Aby se žáci mohli v učebních úlohách angažovat, je důležité, aby se orientovali ve fázích učebního procesu a věděli, co se od nich očekává (Janík, Lokajíčková \& Janko, 2012).

Důležitá oborově specifická otázka se týkala volby rozsahu učiva a volby zástupců, prezentovaných organismů, jevů a pojmů. Dle výzkumu, ve kterém se 277 studentů učitelství vyjadřovalo k otázce plánování vyučovací hodiny společně s fakultním učitelem, uvedlo 92,4 \% z nich, že by tato zkušenost byla velmi cenná (Hobson, 2002). Tyto postoje jsou v souladu s našimi výsledky, kdy respondenti nejčastěji získávali informace ohledně rozsahu učiva právě od svých fakultních učitelů.

Není také divu, že se respondenti při volbě rozsahu učiva často (v př́padě volby zástupců/prezentovaných organismů/jevů/pojmů dokonce nejčastěji) orientovali dle učebnic, nebot se jedná o didaktické médium, které obsah vzdělávání nejen vymezuje, 
ale zároveň i metodicky ztvárňuje (Maňák, 2007). I dotazovaní učitelé z výzkumu Lidstone (1990), který se zabýval vyučovacími hodinami jiného z př́rodovědných předmětů, uvedli, že učebnice využívají především jako zdroj obsahu učiva.

Zároveň je však nutné, aby se učitel nad hloubkou a šiří konkrétního tématu zamýšlel sám v rámci procesu didaktické analýzy učiva, kdy dochází $\mathrm{k}$ vytváření jakéhosi „mostu“, díky kterému je látka žákům zprostředkována tak, aby vyučování probíhalo hladce (Švec, Filová \& Šimoník, 2004). Jak uvádí Knecht a Janík (2008), procesy tvorby a výzkumu učebnic u nás existují spíše nezávisle na sobě, proto jsou učebnice použivány spíše z hlediska zdroje obsahu učiva (srovnej - viz výše v textu), ale ne jako pomůcka, která by z hlediska uváděných aktivit a úkolů odpovídala potřebám a možnostem žáků (Lindtone, 1990). Tomu by se dalo předejít implementací, tzv. strategií design based research - vytvářející takové učebnice, které jsou následně zkoumány v praxi a na základě zpětné vazby revidovány (Knecht \& Janík, 2008).

Velmi zarážející je fakt, že respondenti při procesu zvažování rozsahu učiva téměř vůbec nenahlíželi do školních kurikulárních dokumentů, jako je ŠVP (RVP). Přesto dle výsledků výzkumného šetření, se 96,84 \% studentů vyjádřilo, že jsou s RVP ZV seznámeni alespoň částečně (Nelešovská \& Svobodová, 2005).

Po stanovení obsahu a rozsahu učiva se garant praxí tázal, jak téma/zástupce demonstrovali, které pomůcky používali a proč je demonstrovali právě tímto zpo̊sobem. Konkrétně se doptával i na výhody, nevýhody, alterace a predikce zvoleného postupu. Vnímání výuky př́rodopisu může být kladně ovlivněno různými faktory, jako je např. volba pomůcek nebo zařazení určitých výukových metod (Kubiatko \& Vlčková, 2011). Z tohoto důvodu je vhodné studentům učitelství poskytnout prostor k úvahám nad zvolenými pomůckami, metodami apod. Právě hospitační rozhovor je dobrou př́íležitostí, nebot otevírá dveře k nastolování nových pohledů. Garant praxí studenta nabádá $\mathrm{k}$ přemýšlení o možných alternativních řešeních a student je poté schopný samostatně uvádět výhody, nevýhody a alterace zvolených postupů (Aderibigbe, Colucci-Gray \& Gray, 2014), jak tomu bylo v našem výzkumném šetř̌ení. Výhody, nevýhody a alterace byly uváděny bez větších problémů. Predikci zvoleného zpo̊sobu demonstrace uvedlo malé množství respondentů.

Při výzkumu jsme dále zjištovali, zda jsou si studenti učitelství vědomi nějakých odborných chyb, které by udělali oni v roli vyučujícího nebo žáci. Studenti učitelství se ve výzkumném šetření (Havel, 2001) vyjadřovali k otázce, v jaké oblasti se během pedagogických praxí zdokonalili. Ve 36,1 \% odpovědí byl zmíněn posun v oblasti plánování výuky, která zahrnovala i organizaci vyučování a časové uspořádání hodiny. V našem výzkumu byla organizace naopak jednou z oblastí, ve které respondenti nejčastěji chybovali. Důvodem opakované identifikace potíží právě v této oblasti může být skutečnost, že časové rozvržení patři mezi oblast, ve které dochází ke zlepšování a zároveň která studentům činí největší potíže (Havel, 2001).

Přesto, že jednou ze základních a nepostradatelných charakteristik efektivní práce učitele je odborná připravenost (Juklová, 2013), je pochopitelné, že respondenti našeho výzkumu zmiňovali rezervy i v této oblasti.

Téměř tř̌etina respondentů ve výzkumu Havla (2001) uvedla, že se domnívají, že se jejich schopnosti v komunikaci mezi učitelem (resp. studentem učitelství v roli učitele) a žákem zlepšily, naše výsledky však poukazují, že komunikace činila respondentům nemalé potíže. Respondenti zmiňovali přeřeknutí, zaskočení při dotazech žáků, nesprávnou formulaci odpovědí apod.

Chyby žáků nebyly reflektovány, a to pouze s jednou výjimkou. Toto potvrzuje skutečnost, že začínající učitelé zaměřují svou pozornost především na sebe na úkor žáků (Simpson, Vondrová \& Žalská, 2017; Němečková \& Pavlasová, 2018). 
Poslední zkoumanou oblastí byla atraktivita vyučovaného tématu pro žáky a volba motivační techniky použitá studenty učitelství. Hrabí (2007) se ve svém výzkumu zabývala nejvíce a nejméně zajímavými tématy pohledem 1232 žáků základní školy. Z výzkumu je patrné, že např. „Mnohobuněčné organismy“ byly nejvíce zajímavým tematickým celkem, dále pak „Ptáci“ byli hodnoceni jako nejvíce zajímavý celek v 7. ročníku. I z našeho hlediska, témata zoologie byla většinou respondenty vnímána jako oblíbená pro žáky. Konkrétně téma „Ptáci“ bylo respondenty výzkumu $2 \times$ vyučováno. Respondenti se $\mathrm{k}$ předpokládané oblíbenosti tématu u žáků vyjádřili pozitivně. S6: „Jo, myslím si, že určitě. Přišla za mnou po hodině slečna, že se jí to líbilo. Ti ptáci, podle mě, se líbili všem.“, S7: „Ano, žáci projevili zájem o výuku, což bylo super."

Téma rostliny bylo naopak respondenty nejčastěji vnímáno jako neoblíbené. Jak je patrné z výsledků šetření Hrabí (2007), i žáci vnímali tematický celek „Nahosemenné rostliny“ jako nejméně zajímavý. Nejednotnost mezi respondenty našeho výzkumného šetření může být způsobena zařazením jiných témat vyučovacích hodin. Zajímavé jsou také výsledky Malcové a Janštové (2018), ze kterých je patrné, že žáci hodnotili obor botanika průměrnou známkou 3 na pětistupňové škále Likertova typu, kdy hodnota 5 odpovídala hodnocení „zcela oblíbený“. Dle těchto výsledků zaujímají tedy žáci k oboru botanika neutrální postoj. Je možné, že žáci vnímají rozdíl mezi tématem nahosemenných a krytosemenných rostlin. Naopak v porovnání tematického celku „Stavba těla a funkce jednotlivých orgánů člověka“ s tématem vyučovacích hodin věnujících se této problematice se výsledky odlišovaly. Žáci toto téma hodnotili jako nejvíce zajímavé na rozdíl od odhadu oblíbenosti tématu u žáků, který nastínili naši respondenti. Nicméně podle Vitáska (2017) a Hanzalové (2019) jsou tato témata také mezi žáky nejvíce oblíbená.

Respondenti zmiňovali i způsoby, jakými se pokoušeli žáky motivovat, a to nejenom v př́ipadech, kdy témata pro žáky nebyla zajímavá. Nejčastěji uváděli názornost (prezentace), video a obrázky, což patří určitě mezi doporučované postupy.

Znepokojivě mezi nejméně častý způsob motivace patřilo použíiání př́írodnin a spojení s praxí. Velmi často doporučovaný komplexní výukový př́istup badatelsky orientované výuky nebyl zmíněn ani jedním z respondentů. Zařazování většího množství praktických cvičení do výuky však prokazatelně zvyšuje motivaci žáků ke studiu biologie (Janštová, 2016). Př́rodniny dokonce mají dle Altmanna největší význam pro podnícení vysoké aktivity žáků (Altmann, 1975).

I když jsme si vědomi omezení výzkumu, závislé především na velikosti zkoumaného vzorku, vyplývají z něj některá doporučení pro praxi týkající se především zkvalitnění hospitačních rozhovorů zaváděných do přípravy vzdělávání budoucích učitelů a oblastí, kterým by se měl garant praxí zvýšeně věnovat z důvodu jejich nedostatečného všímání si praktikujících adeptů učitelství.

\section{ZÁVĚR}

Článek představil analýzu hospitačních rozhovorů zaměřených především na oborově specifické jevy ve výuce biologie v pěti tematických oblastech.

Nejčastěji byly stanoveny pouze kognitivní výukové cíle, které byly formulovány především pomocí obsahů učiva. Kličové kompetence a aktivní slovesa byla při stanovení cílů použita v malé míře. Stanovení úspěšnosti dosažení cílů bylo formulováno často jen na laické úrovni.

Rozsah učiva byl nejčastěji určován fakultním učitelem, příp. zvyklostmi dané školy. Prezentované organismy poté nejčastěji pomocí učebnice. Hodnocení volby 
použitých způsobů demonstrace bylo často jen na laické úrovni, studenti zároveň jmenovali jak výhody a nevýhody, tak alterace. Predikce byly uvedeny jen ve velmi malé míře.

Velká část respondentů byla schopna uvést konkrétní chyby, kterých se při výuce dopustili (nejčastěji se jednalo o nějakou odbornou chybu), ovšem k chybám žáků se respondenti nevyjadřovali, a to až na jednu výjimku.

Atraktivita vyučovaných témat pro žáky byla hodnocena většinou studentů učitelství kladně. Mezi kladně hodnocená témata patřila zoologická témata a problematika lidského těla (spojená s praktickými informacemi využitelnými v běžném životě žáků), mezi neoblíbená patřila témata spojená s rostlinami. Jako nejběžnější způsob motivace byla uváděna názornost využitím různých výukových pomůcek.

Domníváme se, že článek může přispět ke zkvalitňování přípravy studentů učitelství na svoji budoucí výuku př́rodopisu/biologie zejména v oblasti vedení hospitačních rozhovorů při souvislých pedagogických praxích.

\section{PoDĚKOVÁNí}

Výzkum byl podpořen projektem Progres Q17 Příprava učitele a učitelská profese $v$ kontextu vědy a výzkumu a dále projektem Podpora pregraduálního vzdělávání na PedF UK č. projektu: CZ.02.3.68/0.0/0.0/16_038/0006965. Naše poděkování patří také všem studentům, kteří v rámci své praxe využili tzv. videohospitaci a následně se zúčastnili hospitačního rozhovoru.

\section{LITERATURA}

Aderibigbe, S. A., Colucci-Gray, L. \& Gray, D. (2014). Mentoring as a collaborative learning journey for teachers and student teachers: a critical constructivist perspective. Teacher Education Advancement Network Journal (TEAN), 6(3), 17-27.

Altmann, A. (1975). Př́rodniny ve vyučování biologii a geologii. Praha: Státní pedagogické nakladatelství.

Altmann, A. \& Jakešová, M. (1975). Metody a zásady ve výuce biologii. Praha: SPN.

Barbetta, P. M., Norona, K. L. \& Bicard, D. F. (2005). Classroom behavior management: A dozen common mistakes and what to do instead. Preventing School Failure: Alternative Education for Children and Youth, 49(3), 11-19.

Barnett, E. \& Friedrichsen, P. J. (2015). Educative mentoring: How a mentor supported a preservice biology teacher's pedagogical content knowledge development. Journal of Science Teacher Education, 26(7), 647-668.

Bernshausen, D. \& Cunningham, C. (2001, březen). The role of resiliency in teacher preparation and retention. Př́spěvek prezentovaný na konferenci American Association of Colleges for Teacher Education 53rd Annual Meeting, Dallas.

Blažek, R. \& Př́hodová, S. (2016). Mezinárodní šetření PISA 2015. Národní zpráva. Př́rodovědná gramotnost. ČŠI, Praha.

Byčkovský, P. \& Kotásek, J. (2004). Nová taxonomie klasifikování kognitivních cílů ve vzdělávání: Revize Bloomovy taxonomie. Pedagogika, 54(3), 227-242.

Dytrtová, R. (2009). Učitel - Př́prava na profesi. Praha: Grada Publishing, a.s. 
Hanzalová, P. (2019). Oblíbenost témat výuky přírodopisu na 2. stupni základní školy [Diplomová práce]. Praha: UK. Dostupné z https://is.cuni.cz/webapps/zzp/detail/200123

Havel, J. (2001). Rozvíjení pedagogických dovedností pohledem studentů. Pedagogická orientace, 11(4), 64-75.

Hendl, J. (2005). Kvalitativní výzkum: základní metody a aplikace. Praha: Portál.

Hobson, A. J. (2002). Student teachers' perceptions of school-based mentoring in initial teacher training (ITT). Mentoring and tutoring, 10(1), 5-20.

Hrabí, L. (2007). Názory žáků a učitelů na učebnice přírodopisu. Pedagogická orientace, $17(4), 28-34$.

Jáč, M. (2017a). Proteosyntéza eukaryot: hledání cesty od znalosti pojmů k hlubšímu porozumění buněčným procesům ve výuce biologie. In J. Slavík, J. Stará, K. Uličná \& P. Najvar, et al., Didaktické kazuistiky v oborech školního vzdělávání (283-308). Brno: Masarykova univerzita.

Jáč, M. (2017b). Pozorování a porovnávání ve výuce př́írodopisu. In J. Slavík, J. Stará, K. Uličná \& P. Najvar, et al., Didaktické kazuistiky v oborech školního vzdělávání (267-282). Brno: Masarykova univerzita.

Janík, T. (2007). Cílová orientace ve výuce fyziky: exkurz do subjektivních teorií učitelů. Pedagogická orientace, 17(1), 12-33.

Janík, T., Lokajíčková, V. \& Janko, T. (2012). Komponenty a charakteristiky zakládající kvalitu výuky: přehled výzkumných zjištění. Orbis scholae, 6(1), 27-55.

https://doi.org/10.14712/23363177.2015.31

Janík, T., Píšová, M., \& Spilková, V. (2014). Standardy v učitelské profesi: zahraniční př́istupy a pokus o jejich zhodnocení. Orbis scholae, 8(3), 133-158.

https://doi.org/10.14712/23363177.2015.61

Janštová, V. (2016). Vliv praktické výuky na motivaci žáků středních škol ke studiu biologie [Disertační práce]. Praha: UK.

Dostupné z https://is.cuni.cz/webapps/zzp/detail/120124

Jelemenská, P. (2007). Problém vytvorenia učebného prostredia v odborových didaktikách. Didaktika biológie z pohladu modelu didaktickej rekonštrukcie. Pedagogika, $57(2), 153-165$.

Juklová, K. (2013). Začínajici učitel z pohledu profesního vývoje. Hradec Králové: Gaudeamus.

Kalhous, Z. \& Obst, O. (2000). Školní didaktika. Olomouc: Univerzita Palackého.

Keller, J. M. (2000, únor). How to integrate learner motivation planning into lesson planning: The ARCS model approach. Př́spěvek prezentovaný na konferenci VII Semanario, Santiago. Dostupné z https://app.nova.edu/toolbox/ instructionalproducts/ITDE_8005/weeklys/2000-Keller-ARCSLessonPlanning.pdf

Knecht, P. \& Janík, T. (2008). Učebnice z pohledu pedagogického výzkumu. In P. Knecht \& T. Janík, et al., Učebnice z pohledu pedagogického výzkumu (9-17). Brno: Paido.

Koštálová, H. \& Hausenblas, O. (2004). Plánování pozpátku. Kritické listy, 16, 13-17.

Kubiatko, M. (2012). Bez prírodopisu to nejde alebo ako ho vnímajú žiaci základných škôl. Studia paedagogica, 16(2), 75-88.

Kubiatko, M. \& Vlčková, J. (2011). Návrh výzkumného nástroje na zkoumání postojů žáků 2. stupně ZŠ k př́rodopisu. Scientia in educatione, 2(1), 49-67. 
Kuruc, M. (2016). Motivace a sebe-regulace v př́pravě budoucích pedagogů. In V. Švec, K. Lojdová \& B. Pravdová (Eds.), Sborník z konference Učitelské praxe - současné poznatky a perspektivy (166-171). Brno: Masarykova univerzita. https://doi.org/10.5817/CZ.MUNI.P210-8274-2016

Kyriacou, C. (2004) Kličové dovednosti učitele. Praha: Portál.

Lidstone, J. G. (1990). Researching the use of textbooks in geography classrooms. Internationale Schulbuchforschung, 12(4), 427-444.

Lojdová, K. (2014). „Cítil jsem se jako bachař.“ Reflexe nové sociální role studenty učitelství na praxi. In J. Nehyba, J. Kolář, M. Dubec, V. Smékal, K. Brücknerová, L. Muchová, D. Moree, J. Vaněk, P. Svojanovský, K. Lojdová \& J. Mareš (Eds.), Reflexe mezi lavicemi a katedrou (87-97). Brno: Masarykova univerzita.

Malcová, K. \& Janštová, V. (2018). Jak jsou hodnoceny jednotlivé obory biologie žáky 2. stupně ZŠ a nižšího gymnázia? Biologie - Chemie - Zeměpis, 27(1), 23-34.

Maňák, J. (2007). Učebnice jako kurikulární projekt. In J. Maňák \& P. Knecht (Eds.), Hodnocení učebnic (24-30). Brno: Paido.

Maršák, J. \& Janoušková, S. (2006, prosinec). Trendy v přírodovědném vzdělávání. Metodický portál RVP. Dostupné z

https://clanky.rvp.cz/clanek/c/Z/1055/trendy-v-prirodovednem-vzdelavani.html/

Marzano, R. J. \& Kendall, J. S. (2007). The new taxonomy of educational objectives. California: Corwin Press.

Marzano, R. J. \& Kendall, J. S. (2008). Designing \& assessing educational objectives. Applying the new taxonomy. California: Corwin Press.

Mazáčová, N. (2014). Vybrané problémy obecné didaktiky. Praha: Univerzita Karlova.

Moss, C. M. \& Brookhart, S. M. (2012). Learning targets: Helping students aim for understanding in today's lesson. Alexandria: ASCD.

MŠMT. (2016). Rámcový vzdělávací program pro základní vzdělávání. Praha: NÚV. Dostupné z http://www.msmt.cz

MŠMT. (2007). Rámcový vzdělávací program pro gymnázia. Praha: NÚV.

Dostupné z http://www.msmt.cz

Nelešovská, A. \& Svobodová, J. (2005). Reflexe připravenosti učitelů na tvorbu ŠVP

ZV. In R. Jandová (Eds.), Sborník z konference Př́prava učitelů a aktuální proměny $v$ základním vzděláváni (20-22). České Budějovice: JČU.

Němečková, L. \& Pavlasová, L. (2018). Changes in professional vision in preservice teachers after watching own lesson. In J. Fejfar, M. Fejfarová, M. Flégl, M. Houška, J. Husák, I. Krejčí, H. Urbancová \& M. Hruška (Eds.), Proceedings of $15^{\text {th }}$ international conference efficiency and responsibility in education 2018 (250-256). Praha: Czech University of Life Sciences.

Papáček, M. (2010). Badatelsky orientované přírodovědné vyučování cesta pro biologické vzdělávání generací Y, Z a alfa? Scientia in educatione, 1(1), 33-49.

Pasch, M., et al. (1998). Od vzdělávacího programu k vyučovací hodině. Praha: Portál.

Pavlasová, L. (2014). Přehled didaktiky biologie. Praha: Univerzita Karlova.

Pavlasová, L. (2017a). Komár sedne, bodne, saje aneb skupinové opakování orgánových soustav členovců. In J. Slavík, et al. (Eds.), Didaktické kazuistiky v oborech školního vzdělávání (259-266). Brno: Masarykova univerzita. 
Pavlasová, L. (2017b). Profesní vidění studentů učitelství biologie zaměřené na obor a oborově didaktické jevy. Scientia in educatione, 8(2), 84-99.

Pavlasová, et al. (2015). Př́rodovědné exkurze ve školní praxi. Praha: Univerzita Karlova.

Pavlasová, L., Stará, J., Vondrová, N., Novotná, M., Robová, J. \& Uličná, K. (2017). Výběrové zaměření pozornosti u studentů učitelství a povaha jejich interpretací. Pedagogika, 68(1), 5-24. https://doi.org/10.14712/23362189.2017.625

Pravdová, B. (2013). Já jako učitelka: profesní sebepojetí studentky učitelství v posledním ročníku pregraduální př́ípravy. Pedagogická orientace, 23(2), 174-194.

Rocard, M., et al. (2007). Science education now: A renewed pedagogy for the future of Europe. Luxembourg: Office for Official Publications of the European Communities.

Simpson, A., Vondrová, N. \& Žalská, J. (2018). Sources of shifts in pre-service teachers' patterns of attention: the roles of teaching experience and of observational experience. Journal of Mathematics Teacher Education, 21(6), 607-630.

https://doi.org/10.1007/s10857-017-9370-6

Sitná, D. (2009). Metody aktivního vyučování. Praha: Portál.

Skalková, J. (2007). Obecná didaktika. 2., rozšǐřené a aktualizované vydání. Praha: Grada Publishing, a.s.

Skalková, J. (2007). Kategorie cíle, kompetence, jejich vzájemný vztah a význam pro obsah vzdělávání v kontextu současnosti. Orbis scholae, 2(1), 7-20.

Stará, J. \& Starý, K. (2018) Výukové cíle aneb cesta tam a zase zpátky. Pedagogika, 68(2), 107-129. https://doi.org/10.14712/23362189.2017.1033

Stuckey, M., Hofstein, A., Mamlok-Naaman, R. \& Eilks, I. (2013). The meaning of 'relevance' in science education and its implications for the science curriculum. Studies in Science Education, 49(1), 1-34. https://doi.org/10.1080/03057267.2013.802463

Sultana, Q. \& Klecker, B. M. (1999, listopad). Evaluation of First-Year Teachers' Lesson Objectives by Bloom's Taxonomy. Příspěvek prezentovaný na konferenci The twenty-eight annual conference of the mid-south education research association, Washington, DC. Dostupné z https://files.eric.ed.gov/fulltext/ED436524.pdf

Škoda, J. \& Doulík, P. (2009). Vývoj paradigmat přírodovědného vzdělávání. Pedagogická orientace, 19(3), 24-44.

Švaříček, R. \& Šed’ová, K. (2007). Kvalitativní výzkum v pedagogických vědách: pravidla hry. Praha: Portál.

Švec, V. (2017). Faktory ovlivňující rozvoj pedagogických dovedností studentů. Pedagogická orientace, 12(1), 63-82.

Švec, V., Filová, H. \& Šmoník, O. (2004). Praktikum didaktických dovedností. Brno: Masarykova univerzita.

Tillema, H. \& Van der Westhuizen, G. (2013) Mentoring conversations and student teacher learning. South African Journal of Higher Education, 27(5), 1305-1323. https://doi.org/10.1007/978-94-6300-058-1_2

Urbanovská, E. (2002). Je potřebné a možné rozvíjet schopnost sebereflexe budoucích učitelů. In V. Švec (Eds.), Cesty k učitelské profesi: Utvář́ní a rozvíjení pedagogických dovedností. Brno: Paido.

Vališová, A. \& Kasíková, H. (2007). Pedagogika pro učitele. Praha: Grada Publishing, a. s. 
Veenman, S. (1987, ř́ijen). On becoming a teacher: An analysis of initial training. Př́spěvek prezentovaný na konferenci Conference on Education of the World Basque Congress, Bilbao.

Vitásek, T. (2017). Vztah žáků střední pedagogické školy k biologickému učivu [Diplomová práce]. Praha: UK. Dostupné z https://is.cuni.cz/webapps/zzp/detail/147691

Vohra, C. F. (2000). Changing trends in biology education: An international perspective. In T. Younès (Eds.), Biology International The news magazine of the international union of biological sciences (49-55).

Wernerová, J. (2009). Obtížnost profesních činností učitele z pohledu studentů učitelství, učitelů a oborových didaktiků. Pedagogická orientace, 19(3), 104-117.

Yip, D. Y. (1998). Identification of misconceptions in novice biology teachers and remedial strategies for improving biology learning. International Journal of Science Education, 20(4), 461-477.

LiNDA NĚMEČKOVÁ, linda.nemeckova@pedf.cuni.cz

LENKA PAVlasová, lenka.pavlasova@pedf.cuni.cz

Univerzita Karlova, Pedagogická fakulta

Katedra biologie a environmentálních studií

Magdalény Rettigové 4, 11639 Praha 1, Česká republika 